\title{
Determining water body characteristics of Doñana shallow marshes through remote sensing
}

\author{
Ricardo Díaz-Delgado, Javier Bustamante, David Aragonés and Fernando Pacios \\ Remote Sensing and GIS Lab \\ Estación Biológica de Doñana-CSIC \\ Sevilla, Spain \\ rdiaz@ebd.csic.es
}

\begin{abstract}
We analyze the potential of Landsat TM and ETM images to discriminate inundation, depth and turbidity patterns in the very heterogeneous shallow marshes of Doñana National Park. According to the results we will reconstruct historical changes in such variables with a long time series of Landsat images (MSS, TM and ETM+). For this purpose we sampled 334 ground-truth points simultaneously to 6 Landsat scenes during springtime of 2004, 2005 and 2006. Then we applied statistical models to field data and we predict inundation level, depth and turbidity at every sample unit with reflectivity data. Results show that SWIR band is the best predictor of inundation level at any point (especially in sediment-charged waters and medium-high plant cover). Therefore we propose two statistical models explaining $31 \%$ of deviance for water turbidity and $70 \%$ of deviance depth in inundated areas.
\end{abstract}

Keywords: Inundation; water turbidity; depth; Landsat TM; Doñana marshes

\section{INTRODUCTION}

Doñana marshes occupy almost $500 \mathrm{~km}^{2}$ at the mouth of the Guadalquivir River (SW Spain). Protected since 1968 as National Park, it is the largest wetland in Europe and hundred of waterfowl species breed and stop in these marshes along its migration. Natural inundation takes place between October and Mars mostly by rain in the drainage watershed. Nowadays, tidal influence is not significant since an artificial levée was built in 1984 to retain water inside the marsh as long time as possible, working as a dump and avoiding the entrance of saline waters. In 1998, the toxic spill of the Aználcollar mine led to avoid the supply of the affected river to Doñana marshes (Guadiamar River) and increased the artificial retention of water in the marsh. Historical inundation regime has dramatically changed as a consequence of management decisions. Today, Doñana encompasses an ambitious project to recover natural inundation process by applying widely accepted decisions based on data gathered in the last 10 years on a point station basis.

In this work, we check the ability of Landsat TM images to discriminate flooded areas of the Doñana marshes and to quantify depth and turbidity in very spatially heterogeneous shallow wetlands. We aim at evaluating whether reflectance values of Landsat sensors (MSS, TM y ETM+) aid to reconstruct historical and seasonal changes on physicochemical characteristics of the Doñana shallow marshes. Empirical relationships with such parameters will be reconstructed allowing to characterize the inundation regime.

\section{METHODS}

\section{A. Rationale}

Water bodies have low reflectivity, especially in Near Infrared and Mid Infrared bands (bands 4, 5 and 7 of TM and ETM+). Several procedures have been developed to identify flooded areas based on the low reflectivity of water in these spectral regions. Some indices have been proposed to automatically determine the inundation level in Landsat scenes. Angel-Martinez [1] suggests the CEDEX index to discriminate continental waters:

$$
\mathrm{CEDEX}=(\mathrm{B} 4 / \mathrm{B} 3)-(\mathrm{B} 4 / \mathrm{B} 5)
$$

Where B4 denotes TM or ETM band 4.According to Castaño et al. [2] CEDEX values below 0.4 are inundated areas. Domínguez [3] suggest the Normalized Difference Water Index [4] as very useful to discriminate oligotrophic waters:

$$
\text { NDWI }=(\text { TM2-TM4) } /(\text { TM2+TM4) }
$$

Domínguez argues that the NDWI fails when applied to the airborne sensor ATM-Daedalus images and suggests as better method to simply apply density slicing on the B4 histogram. Kyu-Shun et al. working in wetlands with different turbidity levels [5] show that TM5 is less sensitive to sediment charged waters and therefore the best to delineate the limits of watersoil in turbid waters.

Finally, several authors have argued that the 3d component of Tasseled Cap transformation for TM, known as Wetness, is tightly related to soil wetness. We also compute this index with the coefficients for Landsat 5 and 7 for reflectivity values in order to evaluate the capability for discriminating inundation levels.

This work has been carried out with the funds from OAPN-MMA and CSIC. F. Pacios is granted by the I3P CSIC plan. The authors also want to thank the help in field work of A. Travaini., H. Le Franc, D. Paz, A. Polvorinos and I. Román. We are also grateful to J.C. Gilabert, J.L. Pecharromán and P.L. Porta for the help in the treatment of images. 


\section{B. Field data}

Doñana wetlands are usually covered by emergent or floating plants, have a very variable hydroperiod and show high turbidity values due to suspended sediments (Figure 1). According to such variability we carried out 7 ground-truth samplings simultaneous to 4 Landsat 5 scenes and 2 Landsat 7 scenes.

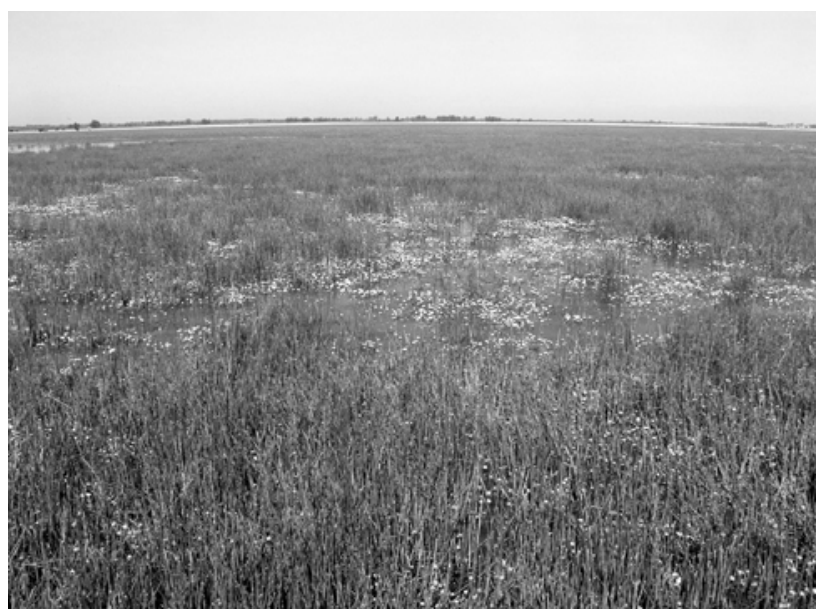

Figure 1. Example of a usual inundated area with a very high plant cover of emergent and floating plants.

The 7 transects were located across heterogeneous inundated areas. Every $200 \mathrm{~m}$ we register the following variables:

TABLE I. VARIABLES, UNITS AND CATEGORIES SAMPLED

\begin{tabular}{|c|c|c|}
\hline Variable & Units & Categories \\
\hline Turbidity & $\begin{array}{ll}\text { Nefelometric } & \text { Turbid } \\
\text { Units } & \end{array}$ & Continuous \\
\hline Depth & Centimeter & Continuous \\
\hline Dry bare-ground cover & Percent per pixel & $\begin{array}{c}0,1-5 \%, 5- \\
25 \%, 25- \\
75 \%,>75 \%\end{array}$ \\
\hline Plant cover & Percent per pixel & $\begin{array}{c}0,1-5 \%, 5- \\
25 \%, 25- \\
75 \%,>75 \%\end{array}$ \\
\hline Open water & Percent per pixel & $\begin{array}{c}0,1-5 \%, 5- \\
25 \%, 25- \\
75 \%,>75 \%\end{array}$ \\
\hline Plant type & Plant species & $\begin{array}{l}\text { Emergent, } \\
\text { floating, } \\
\text { submerged, } \\
\text { algae }\end{array}$ \\
\hline Inundation level & Percent per pixel & $\begin{array}{c}0,1-5 \%, 5- \\
25 \%, 25- \\
75 \%,>75 \%\end{array}$ \\
\hline
\end{tabular}

\section{Spectral separability and statistical models}

We compute the separability [6] of CEDEX, NDWI (with B4 and B5) and Landsat bands to discriminate inundation patterns and physico-chemical characteristics of Doñana shallow marshes. According to the best band/index we apply a regression tree to classify inundation levels (minimum threshold $=5$, minimum sample size $=10$ and minimum deviance $=0.2$ ).

In order to map turbidity and depth we fit in a stepwise mode, a generalized additive model (GAM) to field data by using the best Landsat bands/indices as predictors.

\section{RESULTS}

\section{A. Spectral separability of inundation levels}

Maximum separability values are attained between dry soil ( $0 \%$ inundation class) and fully inundated area ( $>75 \%$ covered by water) with a value of 1.96. Such values correspond to B5 which is the best band/index for 7 of the 10 comparisons. Only for 1 comparison Wetness works better than B5 (5-25\% against 25-75\%) but with a separability value close to B5. Similarly, B4 becomes the best discriminator between the most inundated classes. Finally B7 produced the maximum separability between dry and wet soil.

\section{B. Regression tree}

According to the best model (mean residual deviance $=$ 2.15, 38.8\% of agreement) 4 final classes were selected (Table II).

TABLE II. REGRESSION TREE THRESHOLDS FOR INUNDATION LEVEL

\begin{tabular}{|l|l|}
\hline \multicolumn{1}{|c|}{ B5 Reflectivity } & \multicolumn{1}{c|}{ Inundation level } \\
\hline $0.000-0.105$ & $>75 \%$ \\
\hline $0.105-0.145$ & $25-75 \%$ \\
\hline $0.145-0.199$ & $1-25 \%$ \\
\hline$>0.199$ & Dry soil \\
\hline
\end{tabular}

However, once we merged the 2 most inundated classes and compared to dry soil and 1 to $25 \%$ of inundation per pixel size, the percent of agreement increased up to $95 \%$. Therefore we classify as inundated pixels with B5 reflectivity $<0.145$.

\section{Water turbidity}

Separability computed for 6 NTU ranked classes yielded as the best discriminator the NDWI (calculated with B4). Nonetheless, as a numerical continuous variable we fit the best model to B2, B3 and B7 as the best predictors:

$$
\begin{aligned}
& \log (\mathrm{NTU}+0.01)=2.30-\left(2.55 \cdot 10^{-4} \cdot \mathrm{B} 2\right)+\left(6.00 \cdot 10^{-4} \cdot \mathrm{B} 3\right) \\
& \left(2.31 \cdot 10^{-4} \cdot \mathrm{B} 7\right)
\end{aligned}
$$

B3 is selected by the model directly related to turbidity. B2 may correct for the areas densely covered by vegetation and B7 for locations with very low inundation cover. Final model explains up to $35 \%$ of deviance (Figure 2). 


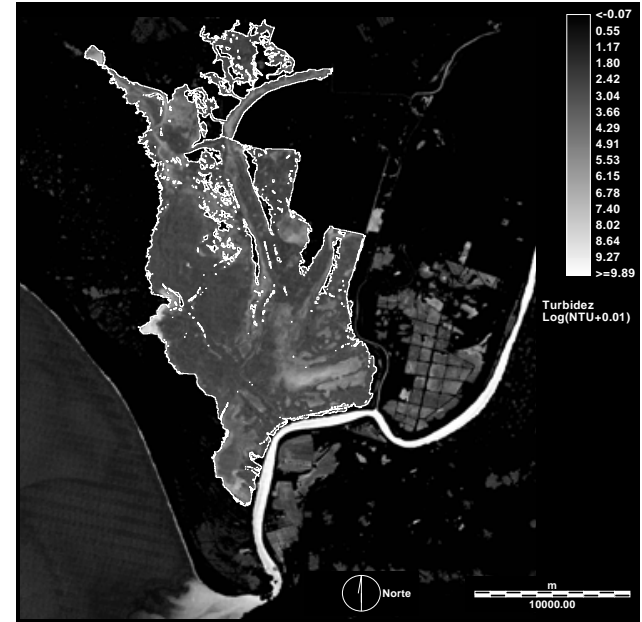

Figure 2. Predicted water turbidity for the 03/25/04 scene. Inundation area is depicted by white line. Notice the river plume.

\section{Water depth}

Unlike for turbidity, depth model selects as the best predictors the NDWI and the CEDEX index, both positively correlated to depth. Besides, B1 also helps to improve the model up to $70.14 \%$ of deviance:

$$
\begin{aligned}
& \log (\text { Depth+1) } \\
& \text { 2.50·NDWI }
\end{aligned}
$$

B1 is inversely related to depth as expected.

\section{DISCUSSION}

Results clearly indicate B5 as the best inundation discriminator, even when compared to proposed better indices in Doñana shallow marshes. That is true even for turbid waters and covered by dense vegetation. On the other hand, B4 is also a very good indicator for percent open water but fails in pixels with sediments-charged waters or emergent vegetation. CEDEX and NDWI indices, although significantly correlated with inundation level, are worse indicators in Doñana wetlands. Water turbidity (Figure 2) and depth can be quantitatively mapped with reflectivity of TM and ETM bands. The turbidity model has to be improved since explains a low but significant percent of the deviance. Depth is better predicted from radiometric data.

\section{REFERENCES}

[1] Ángel-Martínez, M. C. Aplicación de la teledetección en la localización de superficies de agua. CEDEX, Madrid, 1994.

[2] Castaño, S., M. F. Mejuto, A. Vela, A. Quintanilla, and J. R. Ruiz. "Monitoring of wetlands evolution", in Aplication of Space Techniques to the Integrated management of river basin Water Resources (ASTIMwR), S. Montesinos and S. Castaño Eds. Albacete: European Comission, 1999, pp. 27-49.

[3] Domínguez Gómez, J. A. Estudio de la calidad del agua de las lagunas de gravera mediante teledetección. PhD thesis. Alcalá de Henares: Universidad de Alcalá, 2002.
[4] McFeeters, S. K. "The use of the Normalized Difference Water Index (NDWI) in the delineation of open water features”. Int. J. Remote Sens, vol. 17 (7), pp. 1425-1432, 1996.

[5] Kyu-Shun L, K. Tae-Hoon, Y. Yeo-Sang, and S. Sang-Ming. "Spectral characteristics of shallow turbid water near the shoreline on inter-tidal flat”. Korean J. Remote Sens, vol. 17, pp. 131-139, 2001.

[6] Swain, P.H. and Davis, S.M. Remote sensing: the quantitative approach. New York: McGraw-Hill, 1978. 